\title{
ASTROINFORMATICS
}

DOI 10.18524/1810-4215.2021.34.244337

\section{FIRST RESULTS OF PROCESSING DIGITIZED V-PLATES TAKEN WITH THE TAUTENBURG 2m SCHMIDT TELESCOPE}

\author{
V. Andruk, L. Pakuliak, O. Yizhakievych, S. Shatokhina \\ Main Astronomical Observatory NAS of Ukraine, \\ Kyiv, Ukraine, andruk@mao.kiev.ua
}

ABSTRACT. The process of treatment of about 500 digitized plates has started in MAO NAS of Ukraine. Plates were taken with the Tautenburg $2 \mathrm{~m}$ Schmidt telescope in 1963-1989. Linear dimensions of plates are $24 \times 24 \mathrm{~cm}$ with a working field of $3.3 \times 3.3$ degrees and a scale of $51.4 / \mathrm{mm}$. Astronegatives were digitized on the Tautenburg Plate Scanner in five strips with linear dimensions of $5400 \times 23800$ px. The software developed in MAO NAS of Ukraine for the image processing of these scans takes into account the horizontal overlap and the vertical offset of strips. The photometric range of fixed objects is 12 magnitudes, around $\mathrm{V}=7^{m}$ $19^{m}$, due to the separation of objects into faint and bright parts by their images' diameters. Positions of stars and other fixed objects are obtained in the GAIA DR2 reference system. Magnitudes are defined in the V-band of the Johnson color system. The resulted positional accuracy defined from 180 plates' processing is $\sigma_{R A, D E C}=0.10$ "for both coordinates, photometric error on the whole range of magnitudes is $\sigma_{V}=0.14^{m}$ . The convergence of resulted magnitudes with ones from photoelectric standards' data is $0.19^{m}$.

In parallel with image processing and plate data reduction, the search for minor planets' images was carried out. Nine positions and magnitudes of 4 asteroids registered on the plates obtained in 1963-1965 were defined and used for further analysis.

Keywords: Techniques: image processing, plate digitization; Astronomical data bases; Surveys: FON project; Minor planets, asteroids: general; Methods: data analysis; Catalogs: stellar data catalogs.

АНОТАЦЯ. В ГАО НАН України накопичений досвід з пошуку малих тіл Сонячної системи на фотографічних пластинках, отриманих в рамках проектів масових спостережень неба для створення мільйонних каталогів зір. Як правило, під час редукції цих спостережень увага приділялась розв'язанню головної задачі проекту. Завдяки цьому на пластинках залишалися не обробленими зображення другорядних для поточного проекту об'єктів: рухомих тіл Сонячної системи. Зважаючи на віддаленість у ча- сі цих спостережень, можна сподіватись на виявлення на цих пластинках «нових» старих даних щодо положень та зоряних величин малих планет, комет, супутників великих планет, а саме: зображення об'єктів, які передують їх офіційному відкриттю, унікальні моменти спостережень відомих об'єктів у проміжки часу, коли інші спостереження відсутні.

В ГАО НАН України в 2021 р. розпочато процес обробки сканів 500 платівок, експонованих на 2-м телескопі Шмідта в Таутенбурзі в 1963-1989 рр. Платівки розміром 24 х 24 см мають робоче поле 3.3 х 3.3 градуси, масштаб - 51.4 "/ мм. Фотометрична V система реалізована з фільтром GG11, гранична зоряна величина $\mathrm{V}=20.5^{m}$. Астронегативи оцифровані на сканері Таутенбург в режимі п'яти смуг розміром 5400 х 23800 пікселей кожна. Платівки мають просторову роздільну здатність $2540 \mathrm{dpi.} \mathrm{Для}$ об'єднання смуг в цілісне зображення і подальшої обробки сканів цих платівок створено програмне забезпечення, яке враховує перекриття по горизонталі і зміщення сканів по вертикалі. За рахунок розділення об'єктів на яскраві та слабші (з врахуванням розмірів зображень) біля $\mathrm{V}=12^{m}$ зоряної величини, фотометричний діапазон реєстрації складає 12 зоряних величин (від $\mathrm{V}=7^{m}$ до $19^{m}$ ). Координати зір та інших зареєстрованих об'єктів отримано в системі каталога GAIA DR2, зоряні величини в системі V Джонсона. За результатами обробки біля 180 платівок внутрішня точність для всіх об'єктів складає $\sigma_{R A, D E C}=0.10^{\prime т а ~} \sigma_{V}=0.14^{m}$ для положень і зоряних величин відповідно, а сходимість з фотоелектричними даними дорівнює $0.19^{m}$.

За результатами обробки платівок паралельно проведено пошук наявних зображень астероїдів, визначені їх координати і V зоряні величини. Отримані дані 9 положень астероїдів за період спостережень 1963-1965 рр. використані для подальшого аналізу.

Ключові слова: оцифрування, обробка зображень, фотометрія, аналіз даних, каталоги зоряних даних. 


\section{Introduction}

In 2020, with the kind help of our German colleagues, MAO NAS of Ukraine got access to the archive of digitized images of photographic plates of "Karl Schwarzschild" Tautenburg Observatory (TLS Tautenburg, http://www.tls-tautenburg.de). We are interested in photographic observations in $\mathrm{V}$ and $\mathrm{U}$ color bands of the Johnson system in order to derive $\mathrm{V}, \mathrm{U}$ magnitudes of objects for the photometric supplement of the enhanced version of the FONAC stellar catalog of the FON (Photographic Survey of the Northern Sky) observational project [Andruk et al., 2017; Pakuliak et al., 2016; Yuldoshev et al., 2017; Kokhirova et al., 2021], which is created in the framework of UkrVO project [Vavilova et al., 2012; 2016; 2017]. Earlier, for this purpose, we used U, V plates from the glass archive of the $1.2 \mathrm{~m}$ Schmidt telescope, which were digitized and processed in Baldone observatory (Latvia) [Eglitis et al., 2016; 2018].

For the pilot phase of the photometric supplement project, we used near 180 digitized plate images from the Tautenburg collection exposed in $\mathrm{V}$ color band with the Tautenburg 2m Schmidt telescope ("AlfredJensch-Teleskop") in 1963-1989. Plates' exposures are 1-55 minutes of time, their linear dimensions are $24 \times 24$ $\mathrm{cm}$ with the working field $3.3 \times 3.3$ degrees and a scale of $51.4 \mathrm{arcsec} / \mathrm{mm}$. The $\mathrm{V}$ photometric system was provided by the GG11 filter. The limited magnitude on the plates can reach $\mathrm{V}=20.5^{m}$ (http://www.tlstautenburg.de/TLS/index.php?id $=46 \& \mathrm{~L}=1)$.

Plates were digitized with the Tautenburg Plate Scanner TPS, which was a dedicated photographic plate measuring machine operated during 1998-2010. Each photographic plate was scanned into 5 separate images with linear dimensions 5 400x23 $800 \mathrm{px}$ and the number of gray levels 4096 at a color depth of 12 bits. These images have an overlapping along the X-coordinate by $1000 \mathrm{px}$ and a shift along the Y-coordinate by $\pm 800 \mathrm{px}$.

\section{Image processing and plate reduction}

Plates were scanned with a resolution of 2540 dpi. At the scale of $51.4 \mathrm{arcsec} / \mathrm{mm}$, it leads to extremely large images of registered bright objects which exceed $100 \times 100 \mathrm{px}$. We already have a wide experience in image processing of plates from the Schmidt telescope (Baldone, Latvia), from which it follows that an increase in resolution does not lead to a significant increase in accuracy. Besides that, the main modules of the MIDAS/ROMAFOT application, which are the base of used software for image processing, can't derive the characteristics for images of objects which exceed the above-said limit. Based on this, to process images at full resolution, we would have to either change the

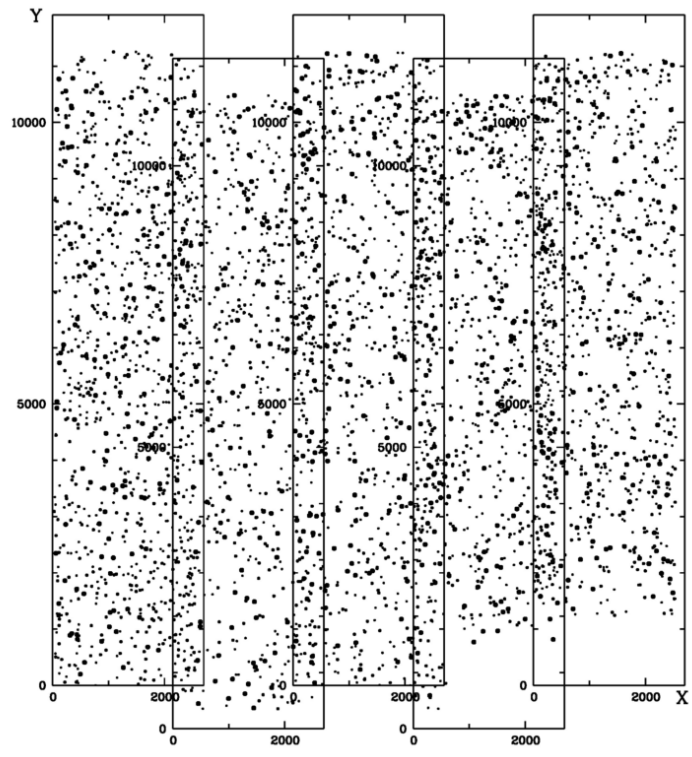

Figure 1: The scheme of a single plate scanning into 5 separate scans

software or significantly rework the used one, including the basic modules, losing noticeably in the time and resources spent. Neither first nor the second meets our goals of the project. The decision was to process plate images halving the resolution to $1200 \mathrm{dpi}$, which corresponds to the linear dimension of scans of $2700 \times 11$ 900. Besides that, to make a correct photometric treatment of bright objects, the whole array of objects was divided by diameters of images into bright and faint ones near the $12^{m}$. Bright objects were additionally filtered four times with different enlarged smoothing windows. This procedure provided the absence of several incidental objects generation instead of one central object. In this case, the characteristic curve for these bright objects shifts along the axis of the instrumental photometric data $\mathbf{m}$ in respect to the characteristic curve of the faint objects. The value of the shift $\Delta \mathbf{m}$ depends on the duration of the exposure, the number of filtering steps, and the filtration window. This value was derived separately for each astronegative.

Figure 1 shows the scheme of a single plate scanning into 5 separate scans overlapped by X-coordinate and shifted by Y-coordinate. After the correct joining of 5 images into the full image of the plate, the last was processed as a whole.

The reduction of the rectangular coordinates $\mathrm{X}$, $\mathrm{Y}$ into the GAIA DR2 reference system was made pursuant to the practice adopted in the FON project [Yuldoshev et al., 2019]. Figure 2 presents the results of the reduction of the test plate (13Sept1964, exposure $\left.=30 \min , \mathrm{RA}=0^{h} 39^{m} 59^{s}, \mathrm{DEC}=40^{\circ} 29^{\prime}\right)$. In the figure: panels $\mathbf{1 a - 1 f}$ - the start of the reduction, panels $\mathbf{2 a - 2 f}$ - the output of the reduction; bottom-left 

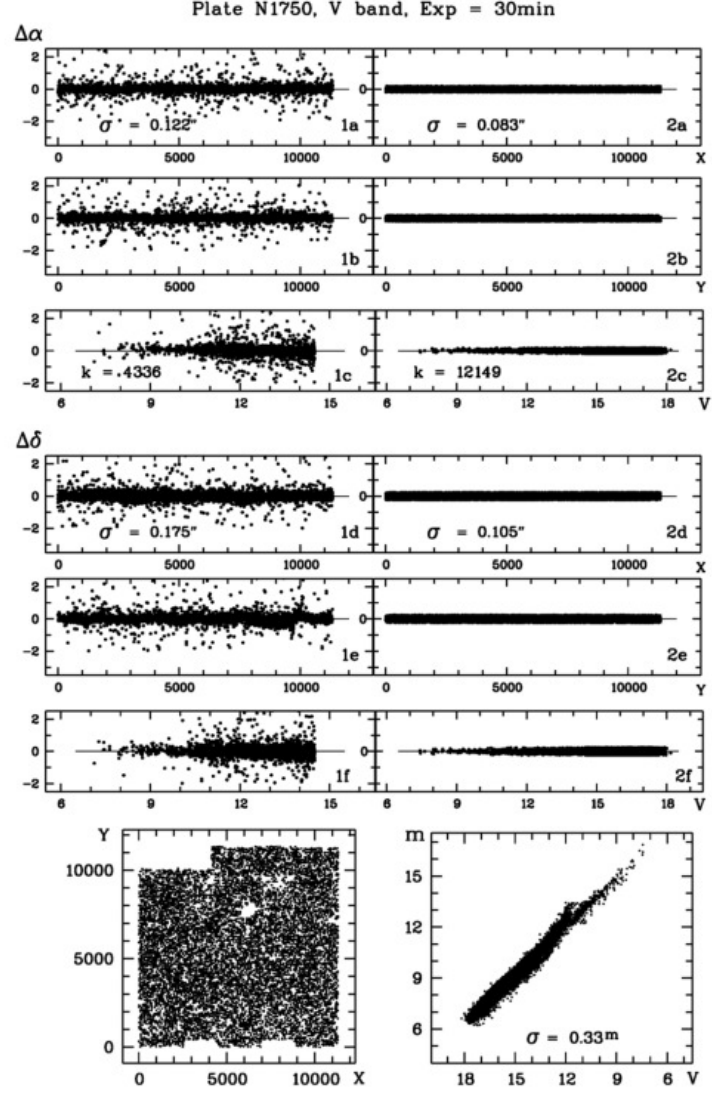

Figure 2: The results of the astrometric reduction of measured coordinates into GAIA DR2 reference system for one of the processed plates

panel - the star map of bright stars, bottom-right one - the binding of the instrumental photometric magnitudes $\mathbf{m}$ to $\mathbf{g}$-magnitudes of GAIA DR2 reduced into V-Johnson system for $\mathbf{k}=12149$ stars.

\section{The binding of BVR Johnson and bgr GAIA DR2 color bands}

As we rarely have enough or don't have at all photoelectric $\mathbf{B}, \mathbf{V}, \mathbf{R}$ Johnson data to build a reference frame for measured objects on the plate, the authors have used (and strongly recommend to do the same in similar cases) magnitudes $\mathbf{b}, \mathbf{g}, \mathbf{r}$ from the GAIA DR2 for the restoration of characteristic curves of each astro negative. From the results, it occurs that for 11 185 stars from the photoelectric sample [Relke et al., 2015] r magnitudes from GAIA DR2 are connected with $\mathbf{R}$ Johnson magnitudes by the equation (1) (the demonstration see in Fig.3):

$$
\begin{gathered}
\mathbf{g}-\mathbf{R}=\underset{ \pm 0.001}{-0.019}+\underset{ \pm 0.004}{0.544}(\mathbf{b}-\mathbf{r})-{ }_{ \pm 0.003}^{0.121}(\mathbf{b}-\mathbf{r})^{2} \\
\sigma=0.066^{m}
\end{gathered}
$$
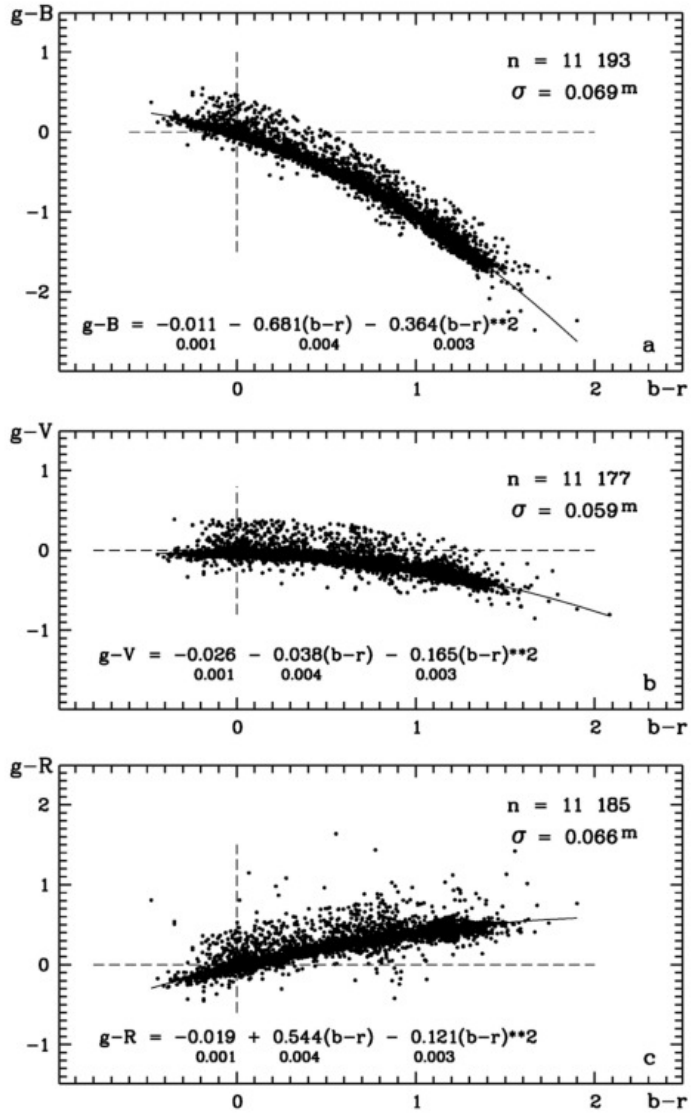

Figure 3: The connection of photoelectric B, V, R Johnson magnitudes with $\mathbf{b}, \mathbf{g}, \mathbf{r}$ magnitudes from the GAIA DR2.

Also, it was found that $\mathbf{b}, \mathbf{g}$ from the GAIA DR2 are reduced into $\mathbf{B}, \mathbf{V}$ Johnson magnitudes by equations (2) and (3):

$$
\begin{gathered}
\mathbf{g}-\mathbf{B}=\underset{ \pm 0.001}{-0.011}-\begin{array}{c}
0.661 \\
\pm 0.004
\end{array}(\mathbf{b}-\mathbf{r})^{-}{ }_{ \pm 0.003}^{0.364}(\mathbf{b}-\mathbf{r})^{2} \\
\sigma=0.069^{m} \\
\mathbf{g}-\mathbf{V}={ }_{ \pm 0.001}^{-0.026}-\begin{array}{c}
0.038 \\
\pm 0.004
\end{array}(\mathbf{b}-\mathbf{r})-{ }_{ \pm 0.003}^{0.165}(\mathbf{b}-\mathbf{r})^{2}, \\
\sigma=0.059^{m}
\end{gathered}
$$

The results of the reduction are demonstrated in Fig.3, panels $\mathbf{a}$ and $\mathbf{b}$. In the figure $\mathbf{n}-$ the amount of stars used for the building of the connection and $\sigma-$ the accuracy of the reduction.

The equations (1) - (3) can be useful for the determination of $\mathrm{B}, \mathrm{V}, \mathrm{R}$ magnitudes on the plates exposed in blue, visual, and red areas of the spectrum in a case of a lack or the absence of photometric standards.

In this work, the authors used equation (3) for the reduction of $\mathbf{g}$ GAIA DR2 magnitudes into $\mathbf{V}$ Johnson ones. 

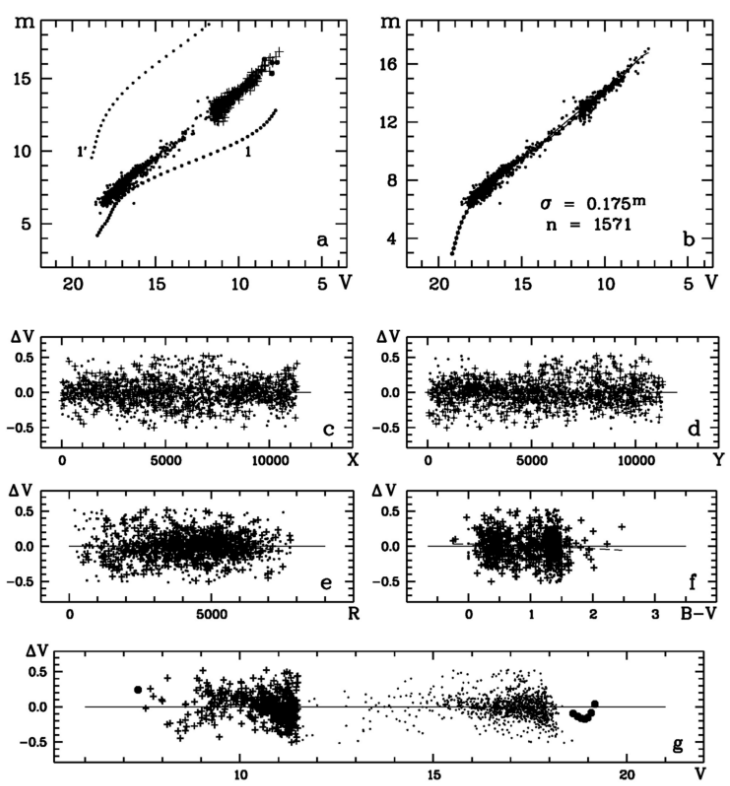

Figure 4: An example of the characteristic curve for the one of the processed plates.

Figure 4 demonstrates an example of the characteristic curve restoration process for the one of the processed plates. In the figure crosses and points are stars from Tycho-2 and GAIA DR2 $(1.25<\mathbf{b}-$ $\mathbf{g}<1.50)$ respectively. The method of characteristic curve restoration for the plates with one exposition developed in MAO NAS of Ukraine was reviewed in detail in [Andruk et al., 2019; Eglitis et al., 2021]. In the figure $\mathbf{1}$ and $\mathbf{1}$ ' are the auxiliary empirical curve and its transformation for the prolongation of the the characteristic curve into the area of faintest stars. Panels c-g show the errors of Johnson V-magnitudes' determination presented as the distribution of differences $\Delta \mathbf{V}$ between measured and reference data in relations to $\mathbf{X}, \mathbf{Y}, \mathbf{R}$ coordinates, $\mathbf{B}-\mathbf{V}$ color indices, and $\mathbf{V}$-magnitudes respectively.

\section{The preliminary assessment of accuracy}

After the processing of $180 \mathrm{~V}$-plate images, the catalog of positions and stellar magnitudes of objects registered on more than one plate was created. The number of records in the catalog is more than 721 thousand objects. The positional accuracy on internal convergence is of $\sigma_{R A, D E C}=0.10$ " and photometric one is of $\sigma_{V}=$ $0.14^{m}$. Figure 5 visualizes the distribution of errors in the catalog. Here, the positional and photometric errors $\sigma_{R A}, \sigma_{D E C}, \sigma_{V}$ are presented on a to $\mathbf{c}$ panels over the intervals of $\mathbf{V}$-magnitudes. Panel $\mathbf{d}$ presents a histogram of star amount distribution with $\mathbf{V}$-magnitude.
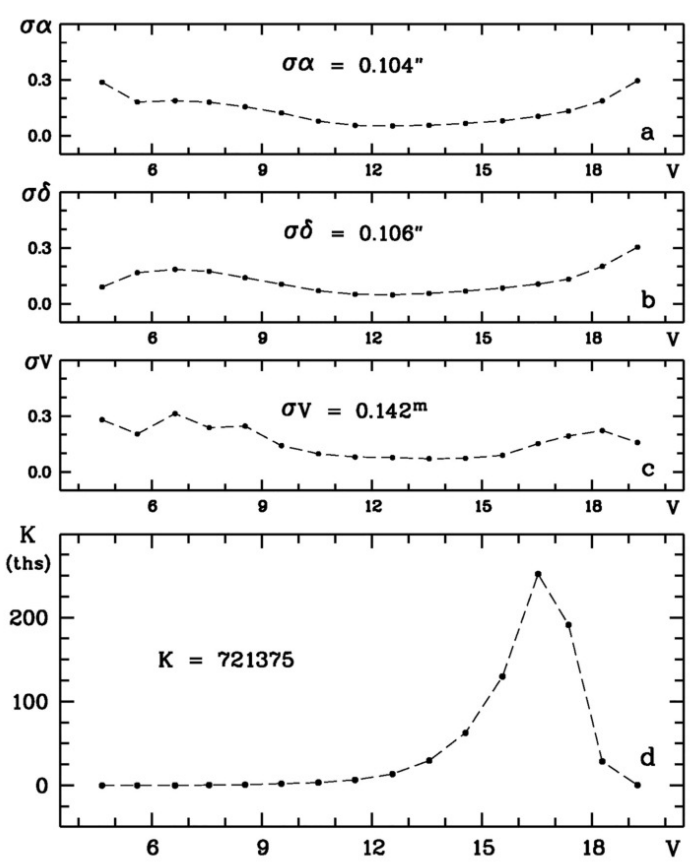

Figure 5: The final accuracy of positions and photometry.

\section{Photometric system of the Tautenburg} Schmidt

Figure 6 demonstrates the photometric $\mathbf{V}$-system of the 2-m Schmidt telescope in Tautenburg in the form of the comparison of final $\mathbf{V}$-magnitudes of the processed plates with the photoelectric data $\mathbf{V}_{\mathbf{p e}}$. In the figure both panels show the trend of differences $\Delta \mathbf{V}=\mathbf{V}-\mathbf{V}_{\text {pe }}$ with $\mathbf{V}$ magnitudes and $\mathbf{B}-\mathbf{V}$ color indices for over 700 stars.

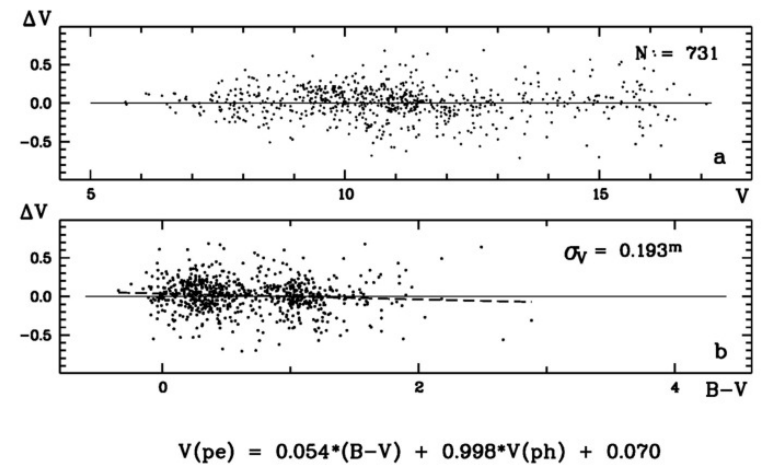

Figure 6: Photometric V-system of the 2-m Schmidt telescope in Tautenburg. 


\section{Asteroids}

In MAO NAS of Ukraine, we accumulated experience in the search of minor planets of the Solar System on the photographic plates obtained in the frameworks of the vast observational projects, which resulted in extensive stellar catalogs containing tens of millions of objects. As a rule, while processing those plates, the attention was paid mostly to the solution of the main goal of the project. As a result, images of secondary objects for the current project remained unnoticed or discarded on the plates. For example, images of moving Solar System bodies. Taking into account the remoteness in time of those observations, one can hope for detection of "new" old data on those plates concerning positions and stellar magnitudes of minor planets, comets, other distant objects. Such data can include, for example, precovery observations or unique observations at moments when other observations were absent, as it was done when searching such objects on the plates of FON project collections [Shatokhina et al., 2018a,2018b; Eglitis, 2019].

\begin{tabular}{|c|c|c|c|c|c|c|c|c|c|c|c|}
\hline Plate & Dat & $e, u$ & JTC & asteroid & & & $\mathrm{RA}$ & & $\mathrm{DE}$ & & $V_{\text {mag }}$ \\
\hline 1232 & 1963 & 09 & 16.986806 & 2145 & 01 & 36 & 57.172 & +29 & 25 & 40.93 & 15.91 \\
\hline 127 & 1965 & 10 & 24.169792 & 383 & 07 & 39 & 28.793 & +21 & 20 & 29.77 & 13.98 \\
\hline 2127 & 1965 & 10 & 24.169792 & 1181 & 07 & 39 & 24.304 & +20 & 54 & 14.29 & 15.08 \\
\hline 134 & 1965 & 10 & 30.069792 & 383 & 07 & 43 & 45.547 & +21 & 14 & 42.30 & 14.41 \\
\hline 134 & 1965 & 10 & 30.069792 & 1181 & 07 & 45 & 08.344 & +20 & 24 & 30.08 & 14.85 \\
\hline 2134 & 1965 & 10 & 30.069792 & 2525 & 07 & 32 & 26.256 & +22 & 00 & 35.29 & 15.90 \\
\hline & 196 & 10 & 101 & 383 & 7 & 85 & & +21 & 14 & 41.42 & 14.26 \\
\hline 2135 & 1965 & 10 & 0.104514 & 1181 & 07 & 45 & 09.503 & +20 & 24 & 23.31 & 14.76 \\
\hline 2135 & 1965 & 10 & 30.104514 & 2525 & 07 & 32 & 26.777 & +22 & 00 & 34.86 & 15.84 \\
\hline
\end{tabular}

Figure 7: Positions and V-magnitudes of asteroids identified on the plates of Tautenburg Schmidt telescope.

Based on the data of processing the plates, a test search for images of asteroids and other objects of the Solar System registered on the plates in moments of their exposition was carried out. 9 positions of 4 asteroids were detected. Positions and $\mathbf{V}$-magnitudes are given in Figure 7 . The defined positions were compared with JPL ephemeris data. The analysis of O-C differences for 2134-2135 pair of plates indicates the evident trend of $\mathrm{O}-\mathrm{C}$, which depends on the rate of change of asteroid coordinates. This trend can also point out a systematic error due to inaccurately recorded moments of the observation. The presented results are preliminary and will be supplemented after a further search across the entire set of plates and an analysis of its results.

\section{Conclusions}

Among the different sections of observational astronomy, photographic astrometry was the one step on the way to astronomy as a big data science due to its ability to produce vast homogeneous observational data arrays. But no doubt that now, with multiple space missions and ground-based automatic facilities, which have taken on this task, the value of old photographic archives as a source of "new" old scientific data only increases. The digitizing of observational archives all over the observatories possessing the glass collections allows successful involving these data into modern-day science. It concerns both the positional data of registered objects of different types and especially photometric ones. Further, the concept of the virtual observatory, within which the open access to the digitized archives is implemented, makes it possible to complement incomplete or gain missing data.

The launched joint project of the compilation of the extended version of the FON (Photographic Survey of the Northern Sky) catalog of stellar positions and B-magnitudes in the sky region from -20 to 90 degrees on declination will contain more than 30 million objects. The photographic base of the project comprises about 5,700 plates obtained at three observatories of the former SU - MAO NAS of Ukraine, Kitab observatory of Uzbekistan, and Gissar observatory of Tajikistan. The mean epoch of the catalog is around 1986. The expected limited stellar magnitude is $\mathbf{B}=17.5^{m}$. To supply and enhance the photometric part of the catalog, we involve the $\mathbf{U}$ and $\mathbf{V}$ plates shot on the $1.2 \mathrm{~m}$ Schmidt telescope in Baldone, Latvia, and the $\mathbf{U}$ and $\mathbf{V}$ plates of Tautenburg Schmidt Telescope (TST), which were kindly provided to us by German colleagues from the open digitized archive of the Thüringer Landessternwarte "Karl Schwarzschild" Tautenburg (TLS).

The test processing of near $180 \mathrm{~V}$-plates and its analysis made it possible to take into account the specific features of digitized images, select the adequate procedure of process, and make the necessary changes to the software. After the processing of $180 \mathrm{~V}$-plate images, the catalog of positions and stellar magnitudes of objects registered on more than one plate was created. The number of records in the catalog is more than 721 thousand objects. The positional accuracy on internal convergence is of $\sigma_{R A, D E C}=0.10$ " and photometric one is of $\sigma_{V}=0.14^{m}$ that meets the requirements of the extended catalog project goals.

The test attempt to search for asteroids on the TST plates has given 9 positions of 4 asteroids. The conclusive decision regarding the possibility of using this photographic material to search for the small bodies of the Solar System can be made after processing and analyzing a sufficient number of plates.

The authors hope that the catalogs of the FON project will be useful in the search for disappeared objects or other transient processes that have occurred in the starry sky [Villarroel et al., 2020, 2021].

Acknowledgements. The authors express their deep 
gratitude to colleagues from the $2 \mathrm{~m}$ Alfred Jensch Telescope of the Thueringer Landessternwarte Tautenburg and the digitized plate archive based on the Tautenburg Plate Scanner [Brunzendorf \& Meusinger, 1999] for kindly providing access to the materials of the digitized plate archive from the Schmidt camera of the $2 \mathrm{~m}$ Alfred Jensch telescope and especially Dr. Helmut Meusinger for his direct participation in organizing the process.

\section{References}

Andruk V., Yuldoshev Q., Eglitis I. et al.: 2017, Odessa Astron. Publ., 30, 159.

Andruk V., Eglitis I., Protsyuk Yu. et al.: 2019, Odessa Astron. Publ., 32, 181.

Brunzendorf J., Meusinger H.: 1999, Acta Historica Astronomiae, 6, 55.

Eglitis I., et al.: 2016. Odessa Astron. Publ., 29, 126.

Eglitis I., Eglite M., Andruk V. et al.: 2018, Odessa Astron. Publ., 31, 208.

Eglitis I., Yizhakevych O., Shatokhina S. et al.: 2019, Odessa Astron. Publ., 32, 189.

Eglitis I., Andruk V. 2021, Open Astronomy, 30, N1,12.
Kokhirova G., Relke H., Yuldoshev Q. et al.: 2021, Odessa Astron. Publ., 34, in press.

Pakuliak L.K., Andruk V.M., Golovnia V.V. et al.: 2016, Odessa Astron. Publ., 29, 132.

Relke E., Protsyuk Yu., Andruk V.: 2015, Odessa Astron. Publ., 28, N2, 211.

Shatokhina S.V. et al.: 2018a, Kinem. Phys. Cel. Bod., 34, N5, 270.

Shatokhina S.V., Relke H., Yuldoshev Q. et al.: 2018b, Odessa Astron. Publ., 31, 235.

Vavilova I.B., Pakuliak L.K., Protsyuk Yu.I. et al.: 2012, Baltic Astronomy, 21, N3, 356.

Vavilova I.B.: 2016, Odessa Astron. Publ., 29, 109.

Vavilova I.B., Yatskiv Ya.S., Pakuliak L.K.: 2017, IAUS, 325, 361.

Villarroel B., Soodla J., Comeron S., et al.: 2020, A.J., 159, 8V.

Villarroel B., Marcy G.W., Geier S., et al.; 2021, NatSR, 11, 12794V.

Yuldoshev Q.X., Ehgamberdiev Sh.A., Muminov M.M. et al.: 2017, Kinem. Phys. Cel. Bod., 33, N5, 250.

Yuldoshev Q., Protsyuk Y., Relke H. et. al.: 2019, Astronomische Nachrichten, 340, N6, 494. 